\title{
Yielding capacity and regeneration of different ages fruit-bearing shoots in sour cherry
}

\author{
Gonda, I. \& Such, Z. \\ University of Debrecen Centre for Agricultural Sciences and Engineering, \\ Department of Horticultural Science and Plant Biotechnology
}

Summary: The yielding potential and regeneration (i.e. germination of hidden buds) after pruning of the fruit-bearing shoots of different ages were compared in sour cherry cultivars pruned to spindle shape. The examinations were carried out in order to determine the optimal pruning strategy resulting in the highest long-term yielding of sour cherry cultivars with intensive crown shape (free and thin spindle shape). According to our results, there are great differences among the studied self-fertile sour cherry cultivars in yielding and regeneration, which are worthwhile to be considered in determining the method and degree of pruning.

Key words: sour cherry cultivars, fruit-bearing potential, pruning method, regeneration

\section{Introduction}

Sour cherry brings fruits on the one-year-old parts (twigs) and on fruit-bearing shoots with short nodules reviving each year that are formed on older parts. With the regular annual pruning, we regulate the processes of growth and the formation of fruit-bearing parts and we ensure and increase the vegetation surplus which delays the inactivation and balding of the different crown parts. Thinning and cutting back the older parts results in a rejuvenation that is in a regular formation of new shoots. Via pruning, the formation of the most valuable fruit-bearing shoots with short nodules is affected on two-year-old and older parts. Of course, in parallel we also ensure good light conditions in the crown.

There are great differences in the growth characteristics of the self-fertile commercial sour cherry cultivars grown in Hungary, which have different effects on balding and regeneration ability.

On the two-, three-, four-year-old and older crown parts the classical fruit-bearing shoots are the bases of yield. The number of these reduces with the crown age as the regeneration, that is the growth of shoots with short nodules from the apical buds and the formation of flower buds on these, is also reducing together with the fruit-setting potential of flowers. Accordingly, balding seems inevitable if a static pruning strategy is applied.

What can be the proper pruning strategy? If a four-yearold part is cut back to a three- or two- or one-year old part, then a four-year-old stump of a certain length remains after the pruning with a three- two- or one-year-old part on it. If we cut it back to a younger branch than the total length of the four-, three-, two- and one-year-old parts is longer, that is the distance from the primary parts (with good transportation) is increased.

However, if we cut back a four-year-old part two a shorter stump, then we have a great loss as those parts that are younger than four-year-old are totally lost. In spite of this, it might be necessary to frequently apply this method in the case of intensive crown shapes (free spindle, thin spindle), because the smaller crown does not enable us to have several-year-old branches except for the central axis and two to three bottom lateral branches. With the aging of the tree, a kind of rotational pruning should be applied to rejuvenate the crown.

Our experiment was carried out at two different growing sites on sour cherry trees of similar age, the fruit-bearing potential of the different parts of the trees and the shoot formation of primary and secondary lateral branches of different ages after cutting back to stumps (vegetative reaction) were determined.

\section{Materials and methods}

\section{Experiment 1:}

Yielding capacity of fruit-bearing shoots of different ages in sour cherry cultivars

Location: Békés county, Csorvás, Hunapfel Ltd.

Orchard characteristics:

Year of planting: autumn of 1996

Rootstock: Prunus mahaleb

Cultivars: 'Újfehértói fürtös', 'Érdi bốtermố, 'Kántorjánosi

3', 'Érdi jubileum', 'Debreceni bốtermố"'

Distance between and within rows: $6 \mathrm{~m} \times 3 \mathrm{~m}$.

Crown shape: free spindle 
The examinations were carried out in the autumn of 2007 before harvest. We measured the basal diameter of one-yearold, two-year-old, etc. twigs on a southern primary branch of 6 trees per each cultivar and we counted the fruits on them. The method was carried out according to the procedure applied by Hrotkó et al. (2005) on cv. 'Újfehértói fürtös'.

The data recorded on the crown parts with different age and thickness were specified for the basal cross-section of the given crown part.

The differences in the thickness of the different crown parts represent the growing dynamics of the twigs which varies greatly among the cultivars.

\section{Experiment 2:}

\section{Regeneration of the fruit-bearing shoots of different ages} in sour cherry cultivars

Location: Demonstration Garden of the University of Debrecen

Year of plantation: spring of 1996

Rootstock: Prunus mahaleb

Cultivars: 'Érdi bótermô', ', Debreceni bốtermô', Kántorjánosi Distance between and within rows: $4 \mathrm{~m} \times 2 \mathrm{~m}$

Crown shape: free spindle

The experiment was set up in February 2007. In the pruning treatment, $50-50 \%$ of the crown parts of different ages were cut back to stumps (of $10-40 \mathrm{~cm}$ length, increasing with age) on 5 trees per each cultivar.

In this pruning treatment, about $50 \%$ of the crown was removed. The trees were unpruned in the previous four years, we set their height as $2.5 \mathrm{~m}$ and we limited also the diameter of the crown. The strong pruning resulted in a strong shoot growth in the experimental year.

At the end of the vegetation period after leaf fall, we quantified the regeneration of the different crown parts that is the data of the shoot formation from the hidden buds.

\section{Results}

\section{Experiment 1:}

Yielding capacity of the fruit-bearing shoots of different ages in sour cherry cultivars

The basal cross-section areas of the twigs of different ages in the different cultivars are shown in Figure 1.

There are no significant differences in the basal diameter of twigs (one-year-old parts) among the cultivars. However, there are great differences in the diameter and thickness of thicker branches. The data of the diagram show that the growth dynamics of the basal diameter of the older branches differs among the cultivars. The thickness of the branches increases linearly with age in cvs. 'Érdi bốtermô', a 'Kántorjánosi 3' and 'Debreceni bốtermô'.

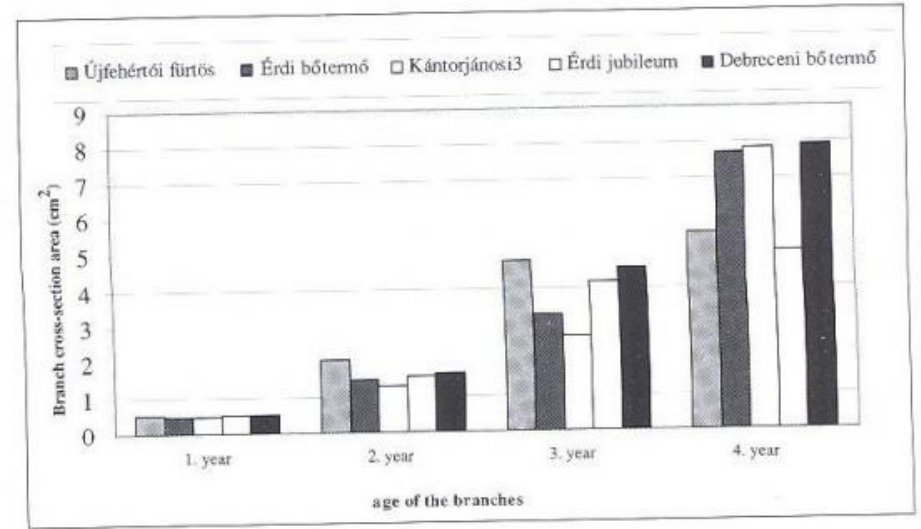

Figure 1 Basal data of the different parts of sour cherry cultivars $\left(\mathrm{cm}^{2}\right)$ (Csorvás, 2007)

This continuous growth might result in a dense canopy, especially if it is accompanied with a proneness to branching.

In the case of cvs. 'Újfehértói fürtös' and 'Érdi jubileum', the growth rate decreases in the fourth year. Based on the above data, the probability of the formation of an unfavourably dense canopy and shadowing of the inner crown parts due to the strong thickening of certain branches is greater for cvs. 'Érdi bótermô', 'Kántorjánosi 3' and 'Debreceni bốtermő'. The tendency of dense canopy formation is smaller in cvs. 'Újfehértói fürtös' and 'Érdi jubileum'.

For determining the degree and the method of pruning, the yielding capacity of the crown parts of different ages should be known. The specific yields of the different parts are presented in Figure 2.

It can be seen in Figure 2 that there are great differences in the yielding capacity of one-year-old parts among the cultivars. 'Kántorjánosi 3' had the highest yield (54 fruits/branch cross-section area $\mathrm{cm}^{2}$ ), cvs. 'Újfehértói fürtös' and 'Érdi bôtermó' also showed high values (about 40 fruits/branch cross-section area $\mathrm{cm}^{2}$ ) However, this value was considerably lower, lower than 20 fruit/branch crosssection area $\mathrm{cm}^{2}$ for cvs. 'Érdi jubileum' and 'Debreceni bốtermô'.

Regarding the productivity of two-year-old twigs, the highest values were measured in cvs. 'Érdi bốtermố and 'Kántorjánosi 3'. As the figure shows, most of the cultivars

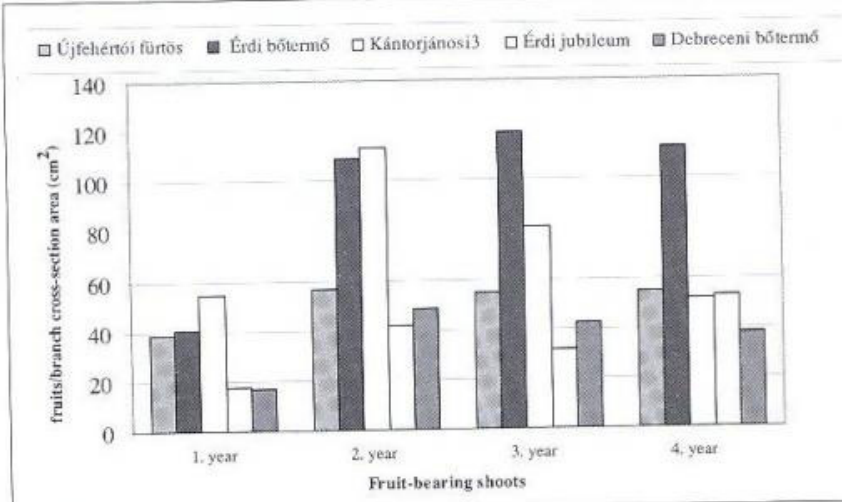

Figure 2 The specific yields of the crown parts of different ages in sour cherry cultivars (Csorvás, 2007) 
reached the maximum specific potential yield per cross-section area already in the two-year-old parts. The only exception was cv. 'Érdi bốtermô', the yielding potential of which was even higher in the three-year-old twigs. When studying the three- and four-year-old twigs, it can be seen that the yielding capacity of $\mathrm{cv}$. 'Kántorjánosi 3' is greatly reduced on such twigs. However, in the other four cultivars, there is no significant difference in the productivity as compared to that of the two-year-old twigs. It is worth mentioning, that the figure represents an outstanding and uniformly high productivity of $\mathrm{cv}$.

Table 1 Recommended pruning methods for crown maintenance in different sour cherry cultivars 'Érdi bốtermô'.

\section{Experiment 2:}

\section{Regeneration of the fruit-bearing shoots of different ages in sour cherry cultivars}

The number of shoots emerging from the buds of the stumps of the three sour cherry cultivars is shown.

Based on the figure, it can be concluded that at what age the branches and twigs should be cut back so that the hidden buds germinate that is the crown is regenerated.

It can be stated that there are great differences in the regeneration of the crown parts of different ages among the cultivars which should be taken into consideration at pruning.

\section{Conclusions and recommendations}

\section{Experiment 1:}

\section{Yielding capacity of the fruit-bearing shoots of different} ages in sour cherry cultivars

Based on our experiments in 2007, we recommend the application of the pruning methods as shown in Table 1.

It can be recommended to leave the twigs until fouryear age if the crown is not dense, because the productivity of such parts is appropriate. 'Kántorjánosi 3' is an exception as its yield decreases already on the three-yearold twigs, therefore, it is worthwhile to remove three-yearold twigs.

The degree of shoot thinning is also an important issue in sour cherry cultivars as most of the yield is produced on the shoots. With thinning, we can greatly influence the yield of trees. Obviously, in cultivars with lower shoot productivity ('Érdi jubileum', 'Debreceni bôtermô') a moderate thinning is recommended.

\section{Experiment 2:}

\section{Regeneration of the fruit-bearing shoots of different ages in sour cherry cultivars}

Based on the data of Figure 3, we can conclude that at what age twigs and branches should be cut back so that the hidden buds germinate that is the crown is regenerated.

It can be stated that germination from stumps in the fifthyear parts is modest in cvs. 'Debreceni bôtermố' and 'Érdi bốtermô'. Therefore, younger parts should be left on them, so regenerative pruning should be applied earlier. However, in cv. Kántorjánosi, germination was the greatest in the case of the stumps of the five-year-old branches. This indicates that even in neglected, unpruned orchards, there is a possibility for the rejuvenation of trees from stumps after pruning the older parts. However, in certain cultivars the regeneration of older parts is uncertain.

Based on our data, there are great differences in the growth and yield characteristics of sour cherry cultivars prone to balding. The more intensive that is the smaller the applied crown shape is, the greater attention should be paid to these characteristics in pruning. The thin spindle form does not allow the maintenance of several-year-old twigs, the one to five-year-old crown parts represent the yielding zone. The rational thinning and pruning of these, with utmost consideration of cultivar characteristics can result in a prolongation of the productive period and an increase of the profitability.

\section{References}

Gonda, I. \& Király, K. (2005): A nyári metszés hatása a meggyfajták növekedésére és gyümölcsminőségére. Kertgazdaság. 37 (1): $45-52$.

Hrotkó, K., Hrotkó, V., Csigai, K. \& Magyar, L. (2005): A karcsú orsó meggyfák termôgallyainak produktivitása. 